\title{
Need Analysis in Learning Media of Digital Engineering Practices
}

\author{
Hamdani $^{1 *}$ and Rahmat Hidayat ${ }^{2}$ \\ ${ }^{12}$ Electrical Engineering Department, Engineering Faculty, Universitas Negeri Padang, 25131, Padang, Indonesia \\ *Corresponding author. Email: hamdani@ft.unp.ac.id
}

\begin{abstract}
The practice is an important factor in improving student skills in learning. However, so far the learning media are not supported so that learning activities are not smooth. The purpose of this research is to describe the level of need for learning trainers that need to be developed for the Digital Engineering Practice course. This type of research is ex post facto with descriptive data analysis techniques. The research subjects were students of the Industrial Electrical Engineering Study Program. Data were collected through observation, interviews, and questionnaires. The results showed that in the implementation of the Digital Engineering Practice, learning trainers were needed who could accommodate the workshop series on the job sheet and students needed trainers who could make various applicative and interesting work series. This study is part of the initial study of the development of a digital engineering practice trainer.
\end{abstract}

Keywords: Digital Engineering Practices, Needs analysis, learning media

\section{INTRODUCTION}

Human Resource Development is enhanced by providing learning with the skills needed by the world of work. [1] The development of education is currently accompanied by technological innovation so that the education system must be in harmony with the world of work. Therefore, skills development is one of the priorities. This is a challenge for Indonesia in b Where employment now requires more labor at the college level. Skills development is the basis of competency-based education developed in higher education. Adjusting the curriculum to the needs of the labor market is a challenge in developing countries building a higher education system that can develop cognitive and quality skills.

To optimize the development of HR implemented through education. [2] In the Indonesian national education system, it has been regulated in the Law of the Republic of Indonesia No 20 of 2003 in article 13 describing the educational pathway consisting of formal, non-formal and informal education that can complement and enrich each other. Then in statement 14 adding formal education levels consist of basic education, secondary education, and higher education while in Article 15 also adds about one type of formal education is vocational. The purpose of vocational education is to produce professional graduates and competence in accordance with the required expertise in business and industry. It is related that the practical activities of $70 \%$ and $30 \%$ theory is Characteristic vocational education. [3] $70 \%$ vocational education practices where students interact more with the practice media. [1] Practical learning is a type of structured experiential learning which is applied when the hands-on experience is needed to learn skills. Therefore, in preparing the curriculum and implementing the learning process, it must refer to the Indonesian National Qualification Framework regulated in Presidential Regulation No. 8/2012. [4] it is an embodiment of the quality and identity of the Indonesian nation is an assessment of the equality of learning outcomes, and a job training system that aims to produce productive Human Resources.

Industrial Electrical Engineering is a D4 study program in the Department of Electrical Engineering, Faculty of Engineering, State University of Padang. In equalizing the learning outcomes generated through education with the level of qualifications in the Indonesian National Qualification Framework, the Electrical Industrial Engineering Study Program (D4) has a level of depth and breadth of material on mastering the theoretical concepts of special sections in the field of knowledge and skills in-depth. [5] The learning outcomes of the Industrial Electrical Engineering Study Program (D4) consists of several parameters in the field of knowledge mastery that is mastering the theoretical 
concepts of the knowledge area needed for analysis, design, and use of technological components at the practical level. While in general skills that can innovate, be independent, be measured, evaluate, and be responsible for the achievement of group work. Then in special skills able to design and conduct experiments, also analyze and interpret data by procedures and standards.

One aspect that supports the learning achievement that matches the level of the Industrial Electrical Engineering study program is learning resources. This becomes essential in the performance of understanding because it increases the learning process to be effective and interactive with courses as facilitators. [6] Whereas students themselves become independent learners and can be used to measure the competencies they have mastered. [7] There are three groups of learning resource categories namely people, environment, and media. [8] [3] Learning media makes it easy for lecturers to communicate learning and improve student skills. Learning media is a learning tool that is based on curriculum and adjusted to the competencies that must be achieved by students. [9] Improving the quality of learning in accordance with technological developments, innovative learning media are required. Therefore, practical learning media are expected that can make it easier for students to understand the material and improve their abilities. [10] The use of media in learning creates meaningful and interesting learning for students. It can be declared that the practice learning media in vocational education is very much expected in the world of work. One effort that can be an alternative is the development of media in the feature of objects (real objects) and provide assignments according to their use in the department of digital electronics directly (contextual).

Therefore, needs analysis is desired to find out students demands for media in practical learning. The results of this analysis can be used as part in the preparation of instructional media so that the student learning experience are more optimal and as expectations. [11] The ability of students depends on the initial ability, motivation, and creativity of students as learners while this limited equipment depends on the availability of practical equipment both in terms of quality and quantity. What is seen in this case is the media as a support for learning. [12] The use of instructional media makes it easy for course subjects to deliver lectures more easily and effectively. Quality media will increase student motivation and creativity in contributing to learning. The needs analysis is performed by examining the semester learning plan and the concept of Digital Engineering Practice substance for students of the Industrial Electrical Engineering Study Program. [13] Observations and interviews are carried out by gathering information related to the implementation of the practice and instructional media used. While the questionnaire was given to lecturers and students who had done Digital Engineering Practices.

Following the description in the Semester Learning Plan (RPS) of the Digital Engineering Practice course, it has an allocation of 2 SKS for 16 meetings for 1 Semester. Consists of practical learning of logic gates, Boolean algebra, and arithmetic circuits, combination circuits, sequential digital circuits such as clock pulse generators, flip-flops, encoder-decoders, asynchronous and synchronous counters, shift registers, multiplexers demultiplexer and ADC-DAC. The results of this study are expected to provide information on learning media that need to be developed in the Digital Electrical Engineering Practice subject. The target of the discussion in the course is understanding the concepts, problemsolving skills, critical thinking of the series arranged and creativity in producing the same purpose.

\section{MATERIALS AND METHODS}

This type of research is ex post facto research with data analysis techniques carried out by descriptive qualitative method. This research was conducted at the Department of Electrical Engineering, Faculty of Engineering, Padang State University. The research population is the 4th-semester students of the Industrial Electrical Engineering Study Program taking Digital Engineering Practices. The research sample was taken randomly, amounting to 48 students.

The research was carried out according to a predetermined schedule. The research instrument used to collect information from respondents. Data was collected by several stages consisting of observation, interviews, and questionnaires. The observations related to the Semester Learning Plan (RPS) in the Digital Engineering Practice course consisted of 16 meetings with 14 face-toface sessions, 1 midterm examination, and 1-semester exam. In implementing the practice, the Digital Engineering Practice job sheet is used as a reference for practice based on the developed semester learning plan. Every meeting students carry out practices with different topics starting from the introduction of basic gates, universal circuit practices, combination circuit practices, basic arithmetic circuit practices, introduction of Boolean algebra methods, flip flop circuit practices, decoder and encoder circuit practices, multiplexer, and demultiplexer circuit practices. To support the use of job sheets, it uses a learning media that is breadboard equipment with its components and a separate power supply. At the trainer, students practice the workshop series that are in the job sheet with direction from lecturers.

The TTL IC component used is still limited only to 
basic logic gates. Meanwhile, in studying the theory they have discussed, it is not only the gate of basic logic. There is no seven segment output available but only uses LED output. Based on the laboratory facilities in supporting Digital Engineering Practices it is less supportive because there is no TTL IC required in a circuit of arithmetic and counter so it cannot be practiced. The output is only LED so the conversion circuit from binary to decimal is also not possible. From the description of topics in each implementation of the practice, students only practice basic digital circuits but no development of logic circuits has been studied before. While the learning outcomes that are following the Industrial Electrical Engineering Study Program can innovate and evaluate a range of practices. Lecturers find it difficult to carry practical learning to students because the learning media used have not been able to accommodate the semester learning plans used so far.

The second data is the result of interviews with several lecturers who support the learning of Digital Engineering Practices. Based on the results of interviews with lecturers in the implementation of Digital Engineering Practices so far in the laboratory takes place by a arranged schedule. Where each class contains 16 students who are divided into four groups. Students are less motivated in participating in practical learning. One reason is the simple practice of learning media because it uses a breadboard and a 5-volt voltage source while others are installed manually. So they need quite a long time to understand the stringing technique properly and quickly. Learning resources used are not able to accommodate the demands of the job sheet used by students. Lack of components of the trainer used takes a long time to complete one practice. Besides, the circuit cannot work well because the components are not good, the voltage drops when making a circuit that uses many TTL IC components. This causes the learning objectives of not fully achieved, in line with the less supportive learning media, it turns out that when the Digital Engineering Practice exam students are given only simple practice questions. Lecturers expect the development of instructional media so that students can practice various types of digital that are appropriate and can guide students to learn independently.

The results of interviews with students who have implemented Digital Practice revealed that the learning media they used was too simple. When first published it is also confused because all components are used separately. Supporting components available in the laboratory are incomplete. When implementing practice some students have difficulty when starting practice. When finished it turned out that the circuit could not work as expected because the collection was not connected properly and the voltage source used was also down during complicated stringing. Students also expect that existing learning media can be developed so that they can support all parts of the job sheet topics available in Digital Engineering Practice. Learning media that are interesting and easy to use will increase students' interest and motivation in participating in Digital Engineering Practices.

The third data is a questionnaire given to students. The questionnaire used was a combination of closed and open questions. The results of the questionnaire analysis of the need for the development of practical learning media show that students expect learning resources that can vary the range of practice so that they are motivated to develop ideas and skills in Digital Engineering Practice. Data obtained from questionnaires that have been answered by respondents. The questionnaire used was a combination of closed and open questions. The question is closed with 2 (two) answer choices, namely "Yes" and "No" then the questions that are combined, namely the choice of answers "Yes" and "No" accompanied by the reasons why the respondent chose "Yes" or "No".Next is the presentation of the results of the analysis of the data obtained. There are three indicators from the questionnaire filled out by students, the first indicator is the available practical learning media consisting of four statement items, the second indicator is the use of existing practice learning media consisting of two statement items and the third is an indicator of solutions to media problems practical learning consisting of four statement items.

\subsection{There are practice learning media available}

In this indicator, there are four items submitted by respondents. Data obtained from the answers provided by respondents is $100 \%$ answered using practical learning media in the implementation of Digital Engineering Practices. $89 \%$ feel that the learning media used cannot support learning and $31 \%$ of respondents have difficulty understanding practical learning material in using the learning media.

\subsection{Use of existing practice learning media}

In this indicator, two statement items are answered by students, where $98 \%$ of students are involved in carrying out practice using learning resources. $89 \%$ felt that the learning media used were incomplete, not interesting, less motivating to take part in practical learning, limited to certain circuits, the basic circuit so that other digital circuits were simulated to obtain data. For more details can be seen in the table below. 
Table 1. Use of existing practice learning media

\begin{tabular}{|l|l|l|l|}
\hline No & Problem & Total & Percentage \\
\hline 1 & $\begin{array}{l}\text { Incomplete } \\
\text { component }\end{array}$ & 16 People & $33,3 \%$ \\
\hline 2 & Less attractive & 17 People & $35,4 \%$ \\
\hline 3 & $\begin{array}{l}\text { Limited to certain } \\
\text { circuits }\end{array}$ & 10 People & $20,8 \%$ \\
\hline 4 & $\begin{array}{l}\text { There isn't any } \\
\text { problem }\end{array}$ & 5 People & $10,4 \%$ \\
\hline
\end{tabular}

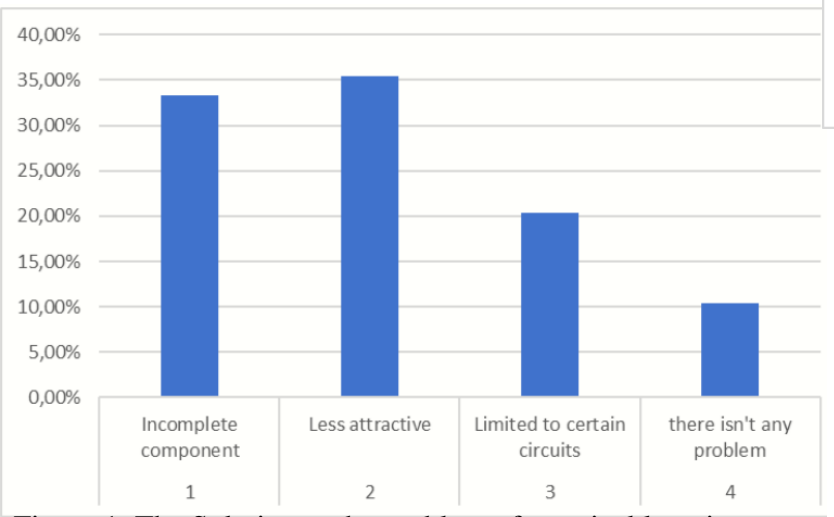

Figure 1. The Solution to the problem of practical learning media

\subsection{The solution to the problem of practical \\ learning media}

Within this indicator, there are four statement items all of which expect improvement and development from the learning media that has been used. Various comments were given by students so that the media used can be developed.

Tabel 2. The solution to the problem of practical learning media

\begin{tabular}{|l|l|l|l|}
\hline No & Solution & Total & Percentage \\
\hline 1 & Attractive design & 8 People & $16,7 \%$ \\
\hline 2 & $\begin{array}{l}\text { Add motivation to } \\
\text { learn }\end{array}$ & 9 People & $18,8 \%$ \\
\hline 3 & $\begin{array}{l}\text { Create creative digital } \\
\text { circuits }\end{array}$ & 9 People & $18,8 \%$ \\
\hline 4 & $\begin{array}{l}\text { Practice learning } \\
\text { media easy to use }\end{array}$ & 5 People & $10,4 \%$ \\
\hline 5 & $\begin{array}{l}\text { Apply from learning } \\
\text { digital engineering } \\
\text { practice theory }\end{array}$ & 8 People & $16,7 \%$ \\
\hline 6 & Complete component & 9 People & $18,8 \%$ \\
\hline
\end{tabular}

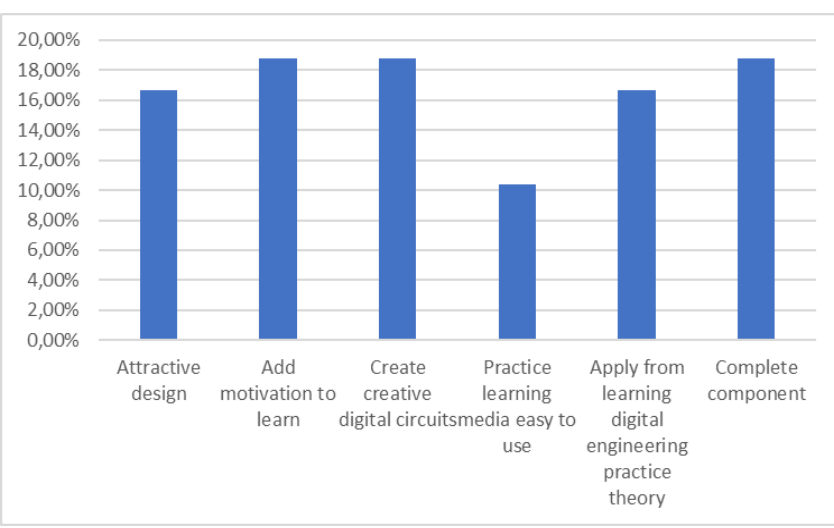

Figure 2. Student expectation that learning media need development

Based on the data obtained, it is necessary to develop learning media for Digital Engineering Practices because it can facilitate students to learn. Both students and lecturers suggest that trainers used in the implementation of Digital Engineering Practices can be updated so that they can provide motivation and learning outcomes in semester learning plans.

\section{CONCLUSION}

Based on research data it can be concluded that learning media in Digital Engineering Practices needs to be developed. This is due to fulfill the objectives of the semester learning plan for Digital Engineering Practices. This developed media can provide convenience in the implementation of the practice. Can be done independently outside of class hours so that students who take Digital Engineering Practices are more skilled and have the skills in applying digital circuits that they have learned from studying Digital Engineering.

\section{ACKNOWLEDGMENTS}

This research would not have been carried out properly without the support of various parties including Padang State University is always funding through PNBP funding from the Institute for Research and Community Service (LP2M) which has provided the opportunity for researchers to be able to participate in the Beginner Research in 2020. Students and Lecturer who has contributed to this research

\section{REFERENCES}

[1] H. Jaya, "Laboratorium virtual mata kuliah praktikum elektronika digital. jurusan pendidikan teknik elektronika fakultas teknik universitas negeri makassar," Elektron. Telekomun. dan Comput., vol. 4, no. 2, pp. 699-710, 2010.

[2] "Undang Undang Republik Indonesia Nomor 20 Tahun 2003.". 
[3] G. P. Cikarge and P. Utami, "Analisis Dan Desain Media Pembelajaran Praktik Teknik Digital Sesuai Rps," Elinvo (Electronics, Informatics, Vocat. Educ., vol. 3, no. 1, pp. 92-105, 2018.

[4] "Peraturan Presiden Republik Indonesia Nomor 8 Tahun 2012 Tentang Kerangka Kualifikasi Nasional Indonesia," 2012.

[5] T. dan P. T. Kementerian Riset, Panduan Penyusun Kurikulum Pendidikan Tinggi, 2nd ed. Jakarta, 2016.

[6] H. Irawati and M. F. Saifuddin, "Analisis Kebutuhan Pengembangan Bahan Ajar Mata Kuliah Pengantar Profesi Guru Biologi Di Pendidikan Biologi Universitas Ahmad Dahlan Yogyakarta," Bio - Pedagog. J. Pembelajaran Biol., vol. 7, no. 96-99, pp. 96-99, 2018.

[7] Kusnandar, "Pengembangan Bahan Belajar Digital Learning Object," J. Teknodik, vol. 17, no. 1, pp. 583595, 2013.

[8] M. Arpan, R. D. A. Budiman, and U. Verawardina, "Need Assessment Penerapan Media Pembelajaran Pengenalan Hardware Jaringan Komputer Berbasis Augmented Reality," Edukasi J. Pendidik., vol. 16, no. 1, pp. 48-56, 2018.

[9] Y. Hendriyani, N. Jalinus, V. I. Delianti, and L. Mursyida, "Analisis Kebutuhan Pengembangan Media Pembelajaran Berbasis Video Tutorial," J. Teknol. Inf. dan Pendidik., vol. 11, no. 2, pp. 2-5, 2018.

[10] W. Althof and M. W. Berkowitz, "Moral education and character education: their relationship and roles in citizenship education," J. Moral Educ., vol. 35, no. 4, pp. 37-41, 2006.

[11] M. Mustafa and U. Rahmah, "Analisis Kebutuhan Terhadap Pengembangan Bahan Ajar Elektronika Digital Di Universitas Negeri Makassar," in Seminar Nasional LP2M UNM, 2017, pp. 705-710.

[12] M. V. Adegbija and M. A. Fakomogbon, "Instructional Media in Teaching and Learning: a Nigerian Perspective," Glob. Media J. African Ed., vol. 6, no. 2, pp. 216-230, 2013.

[13] W. W. Lee and Diana L. Owens, Multimedia - Based Instruction Design Computer Based Training Web -Basd Training Distancee Broadcast Training Performance Based Solutions, Second Edi. San Francisco: Pfeiffer, 2004. 